\title{
A Project to Reduce Canadians' Constitutional Illiteracy
}

\author{
Peter H. Russell
}

How is it determined who is prime minister? Does the leader of the party that wins the most seats in the House of Commons, or that gets the most votes in the election automatically become prime minister? Who appoints cabinet ministers? Do cabinet ministers have to be MPs? Who appoints deputy ministers? What are deputy ministers? What are parliamentary secretaries? What is the PCO? What is the PMO? How is the Governor General selected? What are the Governor General's powers? What is the role of the Queen in governing Canada? What contact, if any, can senior civil servants have with opposition parties? What contact, if any, can government leaders have with judges? How are treaties with foreign countries ratified? Why does Canada have treaties with Aboriginal peoples? Are there any constraints on federal spending in areas of provincial responsibility? What is the constitutional status of the northern territories and how does the federal government's relationship with them differ from its relations with the provinces?

A Canadian citizen who wants to know how her country is governed should be able to get clear, authoritative answers to these questions without much trouble; so should a civics teacher in a school classroom or a person preparing immigrants for Canadian citizenship. These are not small technical questions - they are basic to knowing how Canadian government and democracy work - yet the citizen who looks for answers to these questions in the written text of Canada's Constitution will look in vain.
In the Constitution Act, 1867, and its numerous amendments, she will find only one mention of the prime minister, which does not appear until a 1982 amendment that simply refers to the Prime Minister of Canada attending, along with first ministers of the provinces, a constitutional conference, convened by the prime minister to deal with constitutional matters that concern the rights and status of Aboriginal peoples. The citizen who is likely under the impression that the prime minister has more to do with governing the country than convening constitutional conferences may be surprised to read at the very beginning of the Constitution, in its ninth section, that "The Executive Government and Authority of and over Canada is hereby declared to continue and be vested in the Queen."

The matters these important questions deal with fall into what is referred to as the "unwritten" part of our constitution. There are political science and history books that write about this part of our constitution, but no authoritative text that pulls them all together in a succinct and accessible form. Since 1968 the Government of Canada has maintained a Manual of Official Procedure of the Government of Canada. A citizen who has all the time in the world and tries to wade through the 1500 pages of this dense two-volume Manual will have trouble finding answers to key questions about how our cabinet and parliamentary system of government works while drowning in pages of technical detail about procedural and ceremonial matters. It is certainly no answer to the need for citizens to 
have convenient access to key information about how they are governed.

The fact that important principles and institutions of government are in the informal, "unwritten" part of our constitution is the legacy of our Westminster parliamentary heritage. As Britain evolved from an absolute monarchy into a constitutional monarchy the rules that limit the Crown's power and govern its relationship to the elected house of parliament were never written into a formal constitutional text. Similarly, in the 1840s and 1850s when Britain's North American colonies achieved "responsible government" the rule that the Crown's representative must act on the advice of ministers who command the confidence of the elected house of parliament - was not given formal legal expression. It is therefore not surprising that when the Fathers of Confederation sat down at the Quebec Conference in 1864 to draft Canada's Constitution they saw no need to write into the text rules and principles that were absolutely essential to government operating in a manner consistent with their liberal-democratic principles. In passing the $4^{\text {th }}$ Resolution vesting Executive Authority in the Sovereign, our founding fathers (there were no founding mothers) simply added that this authority was to "be administered according to the well understood principle of the British Constitution." That language was used again in the preamble of the Constitution Act, 1867, which states that "the Provinces of Canada, Nova Scotia and New Brunswick have expressed their Desire to be federally united under the Crown of Great Britain... with a Constitution similar in Principle to that of the United Kingdom."

The Principle referred to is the basic rule of responsible, parliamentary government requiring that government be under the direction and control of ministers accountable to the elected house of parliament. But there are many other rules and principles about how government should be conducted that are not to be found in the written text of the Canadian Constitution. These rules and principles are generally referred to as constitutional conventions.

A recent book on constitutional conventions identifies two kinds of conventions. ${ }^{2}$ One kind, which might be called "core," gives effect to fundamental democratic principles. The principle of responsible government would be a leading example of a core convention. Other conventions are more administrative in nature and deal with the organization and efficient operation of government. It is the executive side of government that is most dependent on conventions, rather than formal legal rules, for regulating how it functions. Parliaments have their own rules of procedure as do courts. Conventions provide stability and predictability to the executive that carries out the day-to-day tasks of governing but in a manner than is more flexible and adaptable than being bound by court-enforced written law. Government leaders and officials certainly need to know and understand these conventions, but citizens too must have easy access to at least the most important of them if they are to know how they are governed. Even if in 1867 this part of our constitution was "well understood" (which I doubt that it was), that surely cannot be said today.

\section{The Cabinet Manuals of New Zealand and the United Kingdom}

New Zealand and the United Kingdom have each produced documents called Cabinet Manuals that do much to alleviate the gap in civic literacy. It is no accident that these two Westminster parliamentary democracies were the first to do this, as neither country has a formal Constitution with the status of a supreme law that cannot be changed by an ordinary Act of Parliament. In New Zealand and the United Kingdom the line between constitutional law and constitutional convention is not as sharply drawn as it is in Australia and Canada, both of which have supreme law Constitutional texts.

New Zealand's Cabinet Manual was first issued in the 1970s as a guide to how those who govern, politicians and officials, should conduct themselves and carry out their responsibilities. ${ }^{3}$ As a compendium of rules, principles and practices of government based on the country's laws and constitutional conventions, New Zealand's Manual covers a wider range of issues than would be expected in a similar document 
for a state like Canada with a written Constitution. For example, it includes sections on ethics, conflicts of interest, privacy, access to information and the legislative process. The authors of a Canadian Manual might omit some or all of these matters, preferring to leave them to the statute book or Parliament's standing orders. However, many of the items it covers, such as the appointment and role of the prime minister (including what should happen when the prime minister is suddenly incapacitated or dies), the formation of cabinet and cabinet decision-making, the caretaker convention, commissions of inquiry, roles and responsibilities of the public service, the link between government and the judiciary, and a rule on omnibus bills, would be useful entries in a Canadian Cabinet Manual.

New Zealand's Cabinet Manual has attained its status as a politically consensual document through an evolutionary process. The endorsement of the Manual is an item on the agenda of the first Cabinet meeting of a new government. Through regular reviews it is updated with new items added and some clarified. Some of these changes reflect developments in the administrative context or constitutional culture. For instance, the 2008 edition of the Manual contains an introductory essay by the Governor General stating that "Certain key elements of the electoral system can be amended only if the people in a referendum approve, or three-quarters of the Members of Parliament agree." ${ }^{4}$ That convention expresses a political consensus built on the experience of a 1993 referendum that approved changing New Zealand's voting system from a first-past-the-post system to a mixed-memberproportional (MMP) system.

The adoption of the MMP electoral system was the key development in elevating the use of New Zealand's Cabinet Manual from being more than a set of guidelines for the executive branch of government. Since the adoption of MMP no election has resulted in a political party winning a majority of seats in New Zealand's Parliament. In this changed political context the Cabinet Manual has proved a valuable guide to how governments are formed after elections, not only for political leaders, senior officials and the
Governor General, but also for the media and the general public. The Manual does not spell out a precise process for forming governments when elections result in a "hung parliament," but makes it clear that "the process of forming a government is political, and the decision to form a government must be made by politicians." The role of the Governor General is "to ascertain where the confidence of the House lies, based on the parties' public statements .... The Manual goes on to state that "It is not the Governor General's role to form the government or participate in negotiations (although the Governor General might wish to talk to party leaders if the talks were to have no clear outcome). "This statement at least makes it clear it is the responsibility of party leaders to work out which combination of parties and in what form of alliance - government coalition, legislative alliance - will be able to command the confidence of Parliament, and that the Governor General should only become involved if they are unable to agree.

Making the Cabinet Manual available on the internet was a giant step in increasing the constitutional literacy of New Zealanders. The hardcopy version is a 156-page (legal size paper) document. Online, with a table of contents setting out its well-organized sections and an index at the end to guide readers to particular topics, it is a handy source of information written in nontechnical, easily understood language about how the country is actually governed.

The immediate incentive for producing a Cabinet Manual in the UK was that anticipation that the 2010 general election in that country would result in a "hung parliament." In late 2009, two NGOs, the Institute for Government and the Constitutional Unit at University College, London, on the basis of the usefulness of New Zealand's Cabinet Manual, advised the Government that the UK would be better prepared for such an election if it had a Cabinet Manual. Prime Minister Gordon Brown accepted the advice and early in 2010 authorized Cabinet Secretary Sir Joe O'Donnell (the equivalent of the Clerk of the Privy Council in Canada) to develop a UK Cabinet Manual. With the election scheduled for early May, the writing first focussed on the formation 
of government after an election. In February, after some input from constitutional scholars, the Cabinet Office published a draft of the "Elections and government formation" chapter. It was then considered by a House of Commons committee, which proposed some improvements that there was not time to incorporate before the election.

The draft chapter seems to have served as a useful guide to politicians, officials, the media and the public when no party won a majority of seats in the May 2010 election. It stated that "The incumbent Prime Minister is not expected to resign until it is clear that there is someone else who should be asked to form a government because they are better placed to command the confidence of Commons and that information has been communicated to the Sovereign." The Manual made it clear that political parties involved in negotiations over the formation of government could call on civil servants for advice on constitutional issues and factual information about policy proposals. ${ }^{7}$ One section spelled out the three broad types of government that could be formed: a single party minority government supported by a series of ad hoc agreements, a formal inter-party agreement such as the Liberal-Labour pact of 1977-78, or a formal coalition government with ministers from more than one political party. ${ }^{8}$ In the end the Conservatives and Liberal Democrats agreed to form a coalition government.

Work on completing the full Cabinet Manual proceeded after the election. A "consultation draft" was issued in late 2010 and examined by three parliamentary committees. ${ }^{9}$ Interaction with parliament did produce some changes in the draft. One such change was a new section stating that on the basis of recent practice, "the Government acknowledges that a new convention had developed in Parliament that before troops were committed the House of Commons should have an opportunity to debate the matter..."10 Though parliamentary discussion influenced the draft, when the UK Cabinet Manual was published in October 2011, the government took the position that formal parliamentary approval of the Manual was not appropriate. Although the Manual has had the benefit of input from parliament and constitutional scholars, it remains a document written by the executive setting out how the government thinks it should use its legal powers in various contexts.

The UK Cabinet Manual is about the same length as New Zealand's and is somewhat less discursive. It is written in clear, precise English. Its chapters on the prime minister, cabinet, cabinet decision-making, and the government's relationships with parliament, the judiciary and the civil service, as well as its chapter 2 on elections and government formation, provide good models for the authors of a Canadian Cabinet Manual. With coverage also of the UK Government's relationship with the devolved governments of Northern Ireland, Scotland and Wales, and with the European Union, the UK Manual, available on the internet, provides a handy, lucid, and informative guide for Britons on how they are actually governed. Constitutional literacy in the United Kingdom has never before been so well served.

\section{Australia's political struggle with constitutional conventions}

Governor General Kerr's dramatic dismissal of Labor Prime Minister Gough Whitlam in 1975 engaged Australia in a distinctive attempt to codify the country's most important conventions relating to parliamentary and cabinet government. After 1975, a Constitutional Convention, originally established by Australian State governments to develop constitutional amendments aimed at curbing the Commonwealth Government's powers, took on the task of fostering agreement among State and Commonwealth leaders on statements spelling out some key constitutional conventions. A 1983 meeting of the Convention in Adelaide "recognized and declared" twenty-five conventions dealing with the powers of the Queen, the office of Governor General and the composition and operation of cabinet. ${ }^{11}$ Two years later in Brisbane, the Convention recognized another seventeen conventions, including several that dealt with the reserve powers of the Crown. However, no agreement was reached on the issue at the centre of the 1975 crisis - the 
circumstances under which the Governor General can dismiss a prime minister.

The Constitutional Convention's intention was to incorporate the agreed-upon statements in the formal text of Australia's Constitution. That never happened. The work of Australia's Constitutional Convention on conventions has left no enduring legacy. Its failure demonstrates the difficulty of trying to obtain a consensus on constitutional conventions in a forum brimming with partisan distrust. More fundamentally, its failure is a monument to the folly of endeavouring to move a host of matters that in Westminster parliamentary systems are best left to be handled through the political process into the formal law of the Constitution.

At the federal level, Australia does have a Cabinet Handbook with roots going back to the 1950s. It deals with the conduct of cabinet business, including rules governing cabinet confidentiality, but has nothing like the scope of the New Zealand and UK Cabinet Manuals. It did not become public until 1984, when the Australasian Political Science Association published it in its journal, Politics. ${ }^{12}$ Revised editions of the Cabinet Handbook are now available on the website of the office of Prime Minister and Cabinet.

\section{Towards a Canadian Cabinet Manual}

In 2011, the first steps towards developing a Canadian Cabinet Manual were taken at a workshop on Constitutional Conventions organized by the Asper Centre for Constitutional Rights at the University of Toronto. Interest in the possibility of "codifying" constitutional conventions had been triggered by what many constitutionalists regarded as the improper use of prorogation by the Harper government. Another concern was statements by Prime Minister Harper about the illegitimacy of coalition governments and by one of his leading advisers asserting that in a modern parliamentary democracy the government should be chosen directly by the electorate. ${ }^{13}$ These assertions clashed with traditional understandings of the conventions governing Canada's Westminster system of parliamentary govern- ment and stimulated interest in trying to establish a consensus on how government should be formed after an upcoming federal election that had a high probability of resulting in a "hung" parliament.

These developments sparked interest among Canadian constitutional scholars in the Cabinet Manuals of New Zealand and the UK. The UK's Manual seemed to have played a useful role in guiding politicians and educating the public in May 2010 when no party won a majority of seats in the UK's general election. Robert Hazell, Professor of Government and the Constitution at University College London, who had played a leading role in initiating the UK's Cabinet Manual project, gave a public lecture about the UK Manual and took part in the workshop discussions. The participants in the workshop included leading constitutional scholars in law and political science, senior advisors to the leaders of all five parliamentary parties, a former Clerk of the Privy Council, the Parliamentary Counsel and an official from the Governor General's office. A list of the participants is provided as an appendix to the published report of the workshop. ${ }^{14}$

The twenty-six person workshop concluded unanimously that "There would be much less risk of a parliamentary crisis following an election in which the result is not clear if there were an authoritative set of guidelines such as New Zealand and the United Kingdom have in their Cabinet Manuals." 15 The workshop concluded that there was a need for much more public consultation and engagement with community organizations and public policy NGOs in order to move toward a Canadian Cabinet Manual. Over the next two years efforts were made to carry out that recommendation. The Ottawa-based Public Policy Forum (PPF) was enlisted as a partner in advancing the project. PPF hosted two roundtable meetings in Ottawa that were attended by government officials and leading media columnists. One of these was attended by Sir Joe O'Donnell, Secretary of the Cabinet in the UK, who explained how the Cabinet Manual had been developed and used in his country. ${ }^{16}$ The Churchill Society for the Advancement of Parliamentary Democracy sponsored a public forum 
in Toronto on the idea of a Cabinet Manual, and there were discussions of the proposal at meetings of the Canadian Political Science Association and the Constitutional Law Section of the Canadian Bar Association. All of these public discussions elicited high levels of support for the proposal and some favourable media commentaries. The Ottawa Citizen's Dan Gardner suggested that the Cabinet Manual, a "sort of pocket guide to Canadian parliamentary governance," would be a worthy way of honouring Jack Layton. ${ }^{17}$

Although Privy Council officials attended the Public Policy Forum roundtables in Ottawa and seemed well disposed towards the development of a Canadian Cabinet Manual, they could not proceed to work on the project and commit resources to it without the permission of the prime minister. Contact was made with a senior official in the Prime Minister's Office who thought it was something in which Prime Minister Harper might well be interested, but the opportunity to brief him did not arise during his time remaining time in office.

\section{A Cabinet Manual's limitations}

In discussions of the Cabinet Manual the most frequently voiced criticism is the danger that such a codification of constitutional conventions might legalize them and bring them before the courts for interpretation and enforcement. Such a legalization of conventions would indeed be unfortunate. It would rob constitutional conventions of their capacity to adapt to changing political circumstances and thrust the judiciary into an area of decision-making for which it has no mandate and is ill-equipped. Courts in Westminster countries have on occasion taken evidence and made determinations on the existence of a convention but they have not purported to make binding rulings enforcing conventions. The courts have left the enforcement of conventions to the political branches of government. The leading example in Canadian history is the Supreme Court of Canada's decision in the 1981 Patriation Reference. ${ }^{18}$

Using the phrase "codifying conventions," as I and others have done, may sound as if the aim or the consequence of a Cabinet Manual is to turn conventions into enforceable rules of law, but that is certainly not the intent. The Manuals are best described as providing guidelines as to how the executive intends to govern and how the public can expect it to govern. Nor has this feared legalization of conventions been a consequence of Cabinet Manuals in New Zealand and the United Kingdom. Many sections of the Manual will be descriptive rather than prescriptive, describing established practice rather than laying down rules of proper behaviour. Non-compliance with normative rules or principles set out in a cabinet manual will not lead to a court challenge but to a weakening of the convention and, unless the non-complying player suffers severe political damage, to its demise. As Sir Ivor Jennings put it in words adopted by the Supreme Court of Canada in the Patriation Reference, a convention only exists if "the persons concerned regarded themselves as bound by it." ${ }^{19}$

The dependence of conventions on consensus among the political actors whose actions the conventions are supposed to regulate points to the weakness of conventions. When a political leader does not accept a law, the law does not die, and serious legal consequences usually follow. But when political actors deny that they are bound by a convention, there goes the convention!

This weakness of constitutional conventions - their legal feebleness - means that there may be rules that we do not want to leave to be regulated by constitutional convention, that we want to legalize. A possible example is prorogation. Disagreement over the proper use of prorogation was evident when Prime Minister Harper in 2008 and 2009 and Ontario Premier McGuinty in 2012 requested that the Crown's representative prorogue parliament in order to avoid meeting the confidence test in the legislature. In March 2010, the House of Commons voted in favour of a motion by NDP Leader, Jack Layton that a prime minister's request to prorogue for more than a week have majority support in the House. The Layton motion could not establish a convention because clearly the Conservatives did not agree with it and the establishment of a convention 
requires broad consensus. In Ontario, an NDP MLA's private member bill would go further than Layton's motion and prohibit a premier from advising the Lieutenant Governor to prorogue the Legislative Assembly without a resolution of support of the Assembly and a recommendation of when the next session of the legislature should begin. $^{20}$

Some constitutionalists think that legislative attempts to control the use of prorogation amount to changes in the office of the Governor General or Lieutenant Governor and therefore require a constitutional amendment supported by Parliament and the legislatures of all ten provinces. However, I think that it would be a stretch for the courts to view legislation framed as limiting what prime ministers or premiers can do as changes to the vice-regal offices. In these recent incidents, the Queen's representative in Ottawa and in Ontario showed no appetite for saying "no" to a first minister's advice on the use of one of the Crown's reserved powers. If the power to close down elected assemblies is not to be a prime minister's or premier's prerogative, Canadians will have to try to legislate reform.

Another matter that might best be dealt with by law rather than convention is when a new parliament should meet after an election. The only rule in our written Constitution that relates to this is section 5 of the Charter, which requires a sitting of the federal parliament and provincial legislatures every twelve months. It would therefore be lawful for a government to delay asking the Governor General to summon a newly elected parliament for up to nearly a year. There is no constitutional convention on this matter. In 1980, after Prime Minister Trudeau resigned and Joe Clark was sworn in as prime minister, Clark waited for nearly five months before advising the Governor General to summon the new Parliament. Our parliamentary democracy is not well served when such a long period can elapse before a government is required to meet the litmus test of its right to govern - commanding the confidence of the elected chamber of parliament.

There was considerable nervousness that if the October 2015 election gave the government a plurality of seats but not a majority, Prime Minis- ter Harper could delay for weeks or even months having parliament meet. While that did not happen, it seems to me that we should not run the risk that it could happen. Canada should join the rest of the parliamentary world that has fixed time periods in their Constitutions for when new parliaments should meet following an election. There being no convention, we must turn to law to establish a firm rule. A recent study suggests that thirty days is the outside limit of the time needed for the formation of government and preparation for its confidence test in the House of Commons. ${ }^{21}$ This law could be established by a constitutional amendment under section 44 of the amending formula, which requires only approval by the federal parliament.

Cabinet Manuals are not meant to be instruments of reform. Their main purpose is to describe existing practices and procedures; however, they can introduce changes in how governments operate, changes that amount to modifications or additions to constitutional conventions. Robert Hazell reports three innovations that the government managed to "sneak" into the UK Cabinet Manual. ${ }^{22}$ Two of them were additions to the caretaker convention (the convention that limits what government can do after the dissolution of parliament). One extended the caretaker convention to a mid-term loss of confidence and another provided for enforcement of the caretaker convention by having a permanent secretary (i.e. deputy minister) request formal direction for any ministerial directive considered improper, a direction that would immediately be made public. The third innovation outlined the role of the civil service in supporting negotiations between the parties in the process of government formation.

That third innovation about civil service advice being available to opposition parties is something that needs attention in a Canadian Cabinet Manual. We learn from David Zussman's book on government transitions that Paul Martin and Stephen Harper set aside the convention that allowed senior civil servants to brief opposition party leaders on policy issues during the election period. ${ }^{23}$ These conversations could provide helpful information about the cost and feasibil- 
ity of policies opposition leaders are considering and prepare the senior public service for what to expect from a potential new government. Zussman believes this kind of interaction between the public service and opposition politicians can be helpful when there is a change of government. Consideration should also be given to this kind of interaction in the process of forming a government after an election in which no party wins a majority of seats. The UK Cabinet Manual stipulates that these contacts between public servants and opposition parties must be authorized by the prime minister and organized by the Cabinet Secretary. Similar provisions in a Canadian Cabinet Manual, while retaining prime ministerial control over these contacts, would enhance the accountability of a prime minister who refuses to allow them.

A Canadian Cabinet Manual might break new ground by including in a section explaining order-in-council appointments the rule that these appointments are made only to positions that become vacant during a government's term of office. The Harper cabinet's decision just before the writ was dropped for the 2015 election to make 49 appointments to positions on government agencies and commissions that would not be open until after the election was a shocking breach of the principle of responsible government. ${ }^{24}$ In reply to a question from Green Party Leader, Elizabeth May on April 13, 2016, Prime Minister Trudeau said that the appointments "were a clear abuse of the appointment process." ${ }^{25}$ The Conservatives have not defended these overreach appointments. A rule against overreach appointments in a Cabinet Manual adopted by the Trudeau Liberals could become the foundation of a new constitutional convention as new governments on taking office review the Manual and accept a rule against such appointments.

\section{The biggest benefit: citizens' constitutional literacy}

A Cabinet Manual can be a quietly evolving instrument for reforming the "unwritten" part of our constitution. It also has the benefit of making political leaders accountable for the conven- tional rules by which they agree to be - or not to be - bound. And make no mistake about it: it is the leaders of the political branches of government who make and modify and sometimes break the conventions of our constitution - the ethical rules and principles about the correct use of legal powers. A little more accountability on these matters is therefore a not a bad thing.

However, in my mind, the biggest benefit a Cabinet Manual would yield for our society is to increase the knowledge of citizens about how they are governed. Most of what would be in the Manual - its bread and butter - are matters that experienced practitioners and teachers of government well know. And most of the information it would contain is buried away in the voluminous Manual of Official Procedure of the Government of Canada. But for the ordinary citizen and many new practitioners - officials and elected politicians - most of what a Cabinet Manual contains will clarify and illuminate the operational reality behind vaguely familiar terms like the Queen's Privy Council, deputy ministers, law officers of the Crown and the PMO.

This increase in popular constitutional literacy would surely improve the quality of our democratic life. Constitutional conventions do not take the form of precise rules that cover every possible circumstance - they have very fuzzy edges. A Cabinet Manual "codifying" what is generally agreed upon would not end debates about whether government or politicians have done the constitutionally correct thing. After an election with an uncertain result, the sections of a Cabinet Manual on the formation of government will not remove the excitement about who will get to govern or spell out precisely a process for making that decision. But a Manual would make it clear that it is the newly elected House of Commons that will decide, not the leader of the party with the most seats nor the Governor General, and it could spell out the optional forms that the new government can legitimately take. That clarification may at least calm things down a little bit, and save so-called "constitutional experts" like the writer of this article from sitting around television studios for hours as the votes come in and are counted. By accessing the online Cabinet 
Manual the media and the citizenry will have a rough idea of the possibilities - and impossibilities - that lie ahead.

Because a Cabinet Manual describes and prescribes what the executive side of government does it must be authorized by the government of the day, and that means the making of it must be authorized by the prime minister. Stephen Harper did not reject the idea of a Cabinet Manual; he simply never had an opportunity to give it careful consideration. Let us hope that Justin Trudeau has an opportunity and gives his cabinet secretariat the go ahead for the project. Its illuminating qualities world certainly fit well with his "sunny ways." But if that hope is not fulfilled, let us not forget that Canada is a federal country with responsible parliamentary and cabinet government at the provincial level with much the same unwritten constitutional rules and practices that apply at the federal level. A provincial premier might well start the ball rolling on a project with such potential to improve the quality of our democratic life.

\section{Endnotes}

1 Constitution Act, 1867 (UK), 30 \& 31 Vict, c 3, s 9, reprinted in RSC 1985, Appendix II, No 5.

2 Brian Galligan \& Scott Brenton, eds, Constitutional Conventions in Westminster Systems: Controversies, Changes and Challenges (Cambridge: Cambridge University Press, 2015) [Constitutional Conventions in Westminster Systems].

3 New Zealand, Cabinet Office - Department of the Prime Minister and Cabinet, Cabinet Manual (Wellington, NZ, 2008), online: <www. cabinetmanual.cabinetoffice.govt.nz>.

4 Ibid at 6.

5 Ibid, ss 6.37-6.39.

6 UK Cabinet Manual Draft, ch 2, s 50. The draft chapter is appended to Robert Hazell, "Genesis of the Cabinet Manual," prepared for the University of Toronto Asper Centre Workshop on Constitutional Conventions, 3-4 February 2011.

7 Ibid, ss 51-53.

8 Ibid, s 55.
9 Robert Hazell, "The United Kingdom" in Brian Galligan \& Scott Brenton, eds, Constitutional Conventions in Westminster Systems, supra note 2.

10 Ibid at 183.

11 Peter H. Russell, "The Politics of Frustration: The Pursuit of Formal Constitutional Change in Australia and Canada" (1988) 6:1 AustralianCanadian Studies 3 at 11.

12 Patrick Weller, "Cabinet Government" in Brian Galligan \& Scott Brenton, Constitutional Conventions in Westminster Systems, supra note 2 at $80-82$.

13 Tom Flanagan, "Only voters have the right to decide a coalition" The Globe and Mail (9 January 2009), online: <www.theglobeandmail.com/ opinion/only-voters-have-the-right-to-decideon-the-coalition/article782719/>.

14 Peter Russell \& Cheryl Milne, Adjusting to a New Era of Parliamentary Democracy, Asper Centre for Constitutional Rights, University of Toronto, 2011, online: <www.ppforum.ca/sites/default/ files/adjusting_to_a_new_era.pdf $>$.

15 Ibid at 11.

16 Public Policy Forum, Government Formation: The Need for Clear Guidelines (Ottawa: 1 June 2011).

17 Dan Gardner, "A Proper Tribute to Jack Layton" Ottawa Citizen (24 August 2011).

18 Re: Resolution to Amend the Constitution, [1981] 1 SCR 753.

19 Sir Ivor Jennings, The Law and the Constitution, 5th ed (London: University of London Press, 1959) at 136.

20 For an account of these events see Peter H. Russell, "Codifying conventions" in Brian Galligan \& Scott Brenton, Constitutional Conventions in Westminster Systems, supra note 2 at 243-44.

21 See Pete H. Russell, Two Cheers for Minority Government: The Evolution of Canadian Parliamentary Democracy (Toronto: Emond Montgomery, 2008) at 147.

22 Robert Hazell, “The United Kingdom”, supra note 9 at 183-84.

23 David Zussman, Off and Running: The Prospects and Pitfalls of Government Transitions in Canada (Toronto: University of Toronto Press, 2013) at 64.

24 Carl Baar \& Peter Russell, "Why won't the Liberals act on Harper's overreach on appointments?" The Globe and Mail (28 March 2016), online: $<$ www.theglobeandmail.com/opinion/whywont-the-liberals-act-on-harpers-overreach-onappointments/article29388808/>.

25 House of Commons Debates, 42nd Parl, 1st Sess, No 38 (13 April 2016) at 1510 (The Rt Hon Justin Trudeau). 
